AL-IQTISHOD: Jurnal Pemikiran dan Penelitian Ekonomi Islam

E-ISSN: 2745-85I2 P-ISSN: 2407-6600

Volume 9 Issue I Januari 202I | Page: 055-072

DOI: $\operatorname{xxxxxxxxxxxxxxx}$

\title{
Asuransi dalam Pandangan Ekonomi Islam
}

\author{
Mochammad Andre Agustianto \\ FEBI UINSA Surabaya \\ andreagustianto@gmail.com
}

Abstract: Insurance or coverage is an agreement between two or more parties, whereby the insurer binds himself to the insured, by receiving an insurance premium, to provide compensation to the insured for the loss, damage or loss expected, or legal liability to a third party that may be suffered the insured, arising from an uncertain event, or to make a payment based on the death or life of an insured person. The insurance has the objective to compensate the insured in accordance with the agreement between the two at the beginning of the agreement. While the benefits of insurance are to provide a sense of security or a sense of security in running a business, can reduce the incidence of losses, can be a tool for capital income for future expectations, etc. In the view of Islam, insurance is allowed because there is no text that prohibits it and has fulfilled the contract or agreement between the two parties who made the agreement and there is no element of coercion and in it there are elements that are mutually beneficial to both.

Keywords: Insurance, Agreements, Premiums, Contract Losses

Abstrak: Asuransi atau pertanggungan adalah perjanjian antara dua pihak atau lebih, dengan mana pihak penanggung mengikatkan diri kepada tertanggung, dengan menerima premi asuransi, untuk memberikan penggantian kepada tertanggung karena kerugian, kerusakan atau kehilangan yang diharapkan, atau tanggung jawab hukum kepada pihak ketiga yang mungkin akan diderita tertanggung, yang timbul dari suatu peristiwa yang tidak pasti, atau untuk memberikan suatu pembayaran yang didasarkan atas meninggal atau hidupnya seseorang yang dipertanggungkan. Asuransi itu mempunyai tujuan untuk mengganti kerugian pada tertanggung sesuai dengan perjanjian diantara keduanya diawal perjanjian. Sedangkan manfaat dari adanya asuransi ialah memberikan rasa terjamin atau rasa aman dalam menjalankan usaha, dapat mengurangi timbulnya kerugian-kerugian, dapat menjadi alat untuk modal pendapatan untuk harapan masa depan dll. Dalam pandangan islam asuransi diperbolehkan karena tidak ada nash yang melarangnya dan sudah memenuhi akad atau perjanjian diantara kedua belah pihak yang melakukan perjanjian itu dan tidak ada unsur paksaan dan di dalamnya terdapat unsur yang saling menguntungkan keduanya.

Kata Kunci: Asuransi, perjanjian, premi, kerugian akad 



\section{A. Pendahuluan}

Pada masa sekarag ini adalah dimana zaman semakin maju dibarengi dengan teknologi yang semakin pesat selain itu kemudahan dalam bertransaksi atau perdagangan sudah bisa diacungi jempol karena dengan kemajuan zaman maka tingkat kepintaran seseorang bisa sangat terpengaruh bahkan dalam dunia industri atau dunia kerja, mereka yang mempunyai perusahaan sendiri bersaing untuk mendapatkan keuntungan dari setiap penjualan produknya tetapi hal tersebut tidak luput dari penawaran atau kesepakatan antara kedua pihak atau produsen dan konsumen tentang jaminan suatu produk yang akan dibeli atau dipakai oleh konsumen. Jaminan tersebut biasa dikenal dengan sebutan asuransi. Asuransi disini dimaksudkan untuk jaminan suatu produk suatu perusahaan tetapi ada juga asuransi yang berupa asuransi jiwa dimana jaminannya itu berupa jaminan kesehatan ataupun anggaran untuk orang yang meninggal, asuransi jiwa biasanya berdiri dalam satu perusahaan sendiri, ya.. biasanya bisa dibilang suatu perusahaan asuransi. Tetapi selain itu masih banyak pula macam-macam asuransi lainnya diantaranya nanti akan dibahas dalam makalah ini.

Asuransi memiliki beberapa macam persyaratan tergantung dari ketentuan produsennya atau pembuat produk yang akan diasuransikannya. Dan dalam ketentuannya itu selalu berbeda-beda ada yang memang merugikan konsumen tetapi menguntugkan bagi produsen dan ada pula yang saling menguntungkan antara kedua belah pihak yaitu menguntungkan bagi konsumen dan menguntungkan pula bagi produsennya. ${ }^{I}$ Dari perbedaan tersebut sehingga memunculkan persepsi dari berbagai kalangan atau para ahli agama khususnya dalam agama Islam mengenai halal dan haramnya penggunaan asuransi, maka dari itu hal tersebut yang melatarbelakangi penulis dalam penulisan makalah ini yaitu yang akan membahas lebih jauh mengenai bolehkah asuransi dipergunakan dalam kehidupan khususnya bagi kalangan orang muslim, apakah haram atau halal asuransi

1 Muhammad Kambali, "MEKANISME PENGELOLAAN DANA TABARRU' ASURANSI SYARIAH PRUDENTIAL LIFE ASSURANCE,” JES (Jurnal Ekonomi Syariah), 2017, https://doi.org/10.30736/jes.v2i1.30.

Volume. 9/No. I/Januari 202I A1-Iqtishod | 55 
Asuransi Dalam pandangan Ekonomi Islam ....

digunakan?. Maka dari sudut pandang tersebut artikel ini akan membahas bagaimana asuransi dan hukumnya dalam agama islam.

\section{B. Kajian Pustaka}

\section{Pengertian Asuransi}

Banyak definisi yang telah diberikan kepada istilah asuransi, dimana secara sepintas tidak ada kesamaan antara definisi yang satu dengan yang lainnya. Hal ini bisa dimaklumi, karena mereka dalam mendefinisikannya disesuaikan dengan sudut pandang yang mereka gunakan dalam memandang asuransi, dimana sesuai dengan uraian diatas bahwa asuransi dapat dipandang dari beberapa sudut.

Asuransi dalam bahasa Belanda di sebut verzekering yang berarti pertanggungan atau asuransi dan dalam bahasa Inggris disebut Insurance. ${ }^{2}$ Ada 2 (dua) pihak yang terlibat dalam Asuransi, yaitu pihak penanggung sebagai pihak yang sanggup menjamin serta menanggung pihak lain yang akan mendapat suatu penggantian kerugian yang mungkin akan dideritanya sebagai suatu akibat dari suatu peristiwa yang belum tentu terjadi dan pihak tertanggung akan menerima ganti kerugian, yang mana pihak tertanggung diwajibkan membayar sejumlah uang kepada pihak penanggung. ${ }^{3}$

Subekti, dalam bukunya memberikan definisi mengenai asuransi yaitu:"Asuransi atau pertanggungan sebagai suatu perjanjian yang termasuk dalam golongan perjanjian untung-untungan (kansovereenkomst). Suatu perjanjian untung-untungan ialah suatu perjanjian yang dengan sengaja digantungkan pada suatu kejadian yang belum tentu terjadi, kejadian mana akan menentukan untungruginya salah satu pihak". ${ }^{4}$

Dasar hukum perjanjian asuransi diatur dalam Pasal 1774 Kitab UndangUndang Hukum Perdata (KUH Perdata), di dalam Kitab Undang-Undang

I J.C.T.Simorangkir,Rudy Erwin,J.T Prasetyo, Kamus Hukum, Sinar Grafika, Jakarta, 2009, hal: I82.

${ }^{3}$ Subekti, Pokok-Pokok Hukum Perdata, PT. Intermasa, Jakarta, 200I, hal: 2I7-2I8

${ }^{4}$ Ibid.

56| A1-Iqtishod Volume. 9/No. I/Januari 202I 


\section{Mochammad Andre Agustianto}

Hukum Perdata pada Pasal 1774 di jelaskan bahwa, Suatu persetujuan untunguntungan ialah suatu perbuataan yang hasilnya, yaitu mengenai untung-ruginya, baik bagi semua pihak maupun bagi sementara pihak, tergantung pada suatu kejadian yang belum pasti.yaitu persetujuan pertanggungan, bunga cagak hidup, perjudian dan pertaruhan. .

Sedangkan Abbas Salim, dalam bukunya memberikan definisi sebagai berikut: "Asuransi ialah suatu kemauan untuk menetapkan kerugian-kerugian kecil (sedikit) yang sudah pasti sebagai pengganti (subtitusi) kerugian-kerugian besar yang belum pasti. Dapat ditarik kesimpulan bahwa, orang bersedia membayar kerugian yang sedikit untuk masa sekarang, agar biasa menghadapi kerugiankerugian besar yang mungkin terjadi pada waktu mendatang”. ${ }^{5}$

Di dalam Kitab Undang-Undang Hukum Dagang (KUHD) Bab Kesembilan pasal 246 dijelaskan tentang pengertian Asuransi yaitu:"Asuransi atau pertanggungan adalah suatu perjanjian ,dengan mana seorang penanggung mengikatkan diri kepada seorang tertanggung, dengan menerima suatu premi untuk memberikan penggantian kepadanya karena suatu kerugian, kerusakan atau kehilangan keuntungan yang di harapkan, yang mungkin akan dideritanya karena suatu peristiwa yang tidak tentu." 6

Dalam pasal ini hanya menyebutkan tentang Asuransi Kerugian tanpa menyebutkan tentang asuransi jiwa.sehingga kemudian diterbitkan Undang-undang khusus tentang perasuransian yaitu undang-undang Nomor 2 Tahun 1992 dimana pada pasal I undang-undang ini menyebutkan : " Asuransi atau pertanggungan adalah perjanjian antara dua pihak atau lebih, dengan mana pihak penanggung mengikatkan diri kepada tertanggung, dengan menerima premi asuransi, untuk memberikan penggantian kepada tertanggung karena kerugian, kerusakan atau kehilangan yang diharapkan, atau tanggung jawab hukum kepada pihak ketiga yang mungkin akan diderita tertanggung, yang timbul dari suatu peristiwa yang tidak

${ }^{5}$ Abbas Salim, Asuransi dan Manejemen Resiko, PT.Raja Grafindo Persada, Jakarta, 2003, hal:I

${ }^{6}$ Pasal 246 Kitab Undang-Undang Hukum Dagang

Volume. 9/No. I/Januari 202I A1-Iqtishod| 57 
Asuransi Dalam pandangan Ekonomi Islam ...

pasti, atau untuk memberikan suatu pembayaran yang didasarkan atas meninggal atau hidupnya seseorang yang dipertanggungkan”. Undang-undang ini memperjelas pengertian asuransi yang merupakan perjanjian dua pihak atau lebih mengenai pergantian atas kerugian, kerusakan atau kehilangan keuntungan yang diderita pihak tertentu.

\section{Tujuan Dan Manfaat Asuransi}

\section{a. Tujuan Asuransi}

Perjanjian asuransi itu mempunyai tujuan untuk mengganti kerugian pada tertanggung, jadi tertanggung harus dapat menunjukkan bahwa dia menderita kerugian dan benar-benar menderita kerugian. Di dalam asuransi itu setiap waktu selalu dijaga supaya jangan sampai seorang tertanggung yang hanya bermaksud menyingkirkan suatu kerugian saja dan mengharapkan suatu untung menikmati asuransi itu dengan cara memakai spekulasi, yang penting ialah bahwa tertanggung harus mempunyai kepentingan bahwa kerugian untuk mana ia mempertanggungkan dirinya itu tidak menimpanya. ${ }^{7}$ Secara umum asuransi mempunyai tujuan sebagai berikut:

\section{I) Pengalihan resiko}

Menurut teori pengalihan resiko (risk transfer theory), tertanggung menyadari bahwa ada ancaman bahaya terhadap harta kekayaan miliknya atau terhadap jiwanya. Jika bahaya tersebut menimpa harta kekayaannya atau jiwanya, dia akan menderita kerugian atau korban jiwa atau cacat raganya. Secara ekonomi, kerugian material atau korban jiwa atau cacat raga akan mempengaruhi perjalanan hidup seseorang atau ahli warisnya. Untuk mengurangi atau menghilangkan beban resiko tersebut pihak tertanggung berupaya mencari jalan kalau ada pihak lainyang bersedia mengambil alih beban resiko ancaman bahaya dan dia sanggup membayar

'Djoko Prakoso, I. Ketut Murtika. Hukum Asuransi di Indonesia. Jakarta: Rineka Cipta, 1989, hal: 9 
kontrak prestasi yang disebut premi. Tertanggung mengadakan asuransi dengan tujuan mengalihkan resiko yang mengancam harta kekayaan atau jiwanya. Dengan membayar sejumlah premi kepada perusahaan asuransi (penanggung), sejak saat itu pula resiko beralih pada penanggung. Apabila sampai akhirnya jangka waktu asuransi tidak terjadi peristiwa yang merugikan penanggung beruntung memiliki dan menikmati premi yang telah diterimanya dari tertanggung. ${ }^{8}$

\section{2) Pembayaran ganti kerugian}

Jikapadasuatu ketika sungguh sungguh terjadi peristiwa yang menimbulkan peristiwa yang menimbulkan kerugian (resiko berubah menjadi kerugian), maka kepada tertanggung yang bersangkutan akan dibayarkan ganti kerugian seimbang dengan jumlah asuransinya. Dalam praktiknya, yang timbul bersifat sebagian (partial loss), tidak semua beruppa kerugian total (total loss) dengan demikian, tertanggung mengadakan asurannsi bertujuan memperoleh pembayaran ganti kerugian yang sunggu-sungguh dideritanya. Jika dibandingkan dengan premi yang diterima dari beberapa tertanggung maka jumlah ganti kerugian yang dibayarkan kepada tertanggung yang menderita kerugian itu tidaklah begitu besar jumlahnya. Kerugian yang diganti oleh penanggung itu hanya sebagian kecil dari jumlah premi yang diterima dari seluruh tertanggung. Dari sudut pandang ekonomi keadaan ini merupakan factor pendorong perkembangan perusahaan asuransi disamping factor tingginya pendapatan perkapita warga Negara (warga masyarakat). ${ }^{9}$

Djoko Prakoso, dalam bukunya menyebutkan, perjanjian asuransi itu mempunyai tujuan untuk mengganti kerugian pada tertanggung, jadi tertanggung harus dapat menunjukkan bahwa dia menderita kerugian dan benar-benar menderita kerugian. Di dalam asuransi itu setiap waktu selalu

${ }^{8}$ Abdulkadir Muhammad, Hukum perdata Indonesia,Bandung: Citra Aditya Bakti, I993, hal: I2-I3

'Ibid., hal. I3-I4

Volume. 9/No. I/Januari 202I A1-Iqtishod|59 
Asuransi Dalam pandangan Ekonomi Islam ....

di jaga supaya jangan sampai orang tertanggung yang hanya bermaksud menyingkirkan suatu kerugian saja dan mengharapkan suatu untung menikmati asuransi itu dengan memakai spekulasi, yang penting ialah bahwa tertanggung harus mmmempunyai kepentingan bahwa kerugian untuk mana ia mempertanggungkan dirinya itu tidak akan menimpanya, ajaran "kepentingan" ini sangat penting di dalam seluruh hukum asuransi. ${ }^{10}$

\section{b. Manfaat Asuransi}

Asuransi selaku lembaga keuangan bukan bank mempunyai peranan cukup besar sekali baik bagi masyarakat maupun bagi pembangunan. Adapun peranan tersebut berupa manfaatnya yang dapat disimpulkan sebagai berikut :

I) Asuransi dapat memberikan rasa terjamin atau rasa aman dalam menjalankan usaha. Hal ini karena seseorang akan terlepas dari kekhawatiran akan tertimpa kerugian akibat suatu peristiwa yang tidak diharapkan, sebab walaupun tertimpa kerugian akan mendapat ganti rugi dari perusahaan asuransi.

2) Asuransi dapat menaikkan efisiensi dan kegiatan perusahaan, sebab dengan memperalihkan risiko yang lebih besar kepada perusahaan asuransi, perusahaan itu akan mencurahkan perhatian dan pikirannya pada peningkatan usahanya.

3) Asuransi cenderung kearah perkiraan penilaiaan biaya yang layak. Dengan adanya perkiraan akan suatu risiko yang jumlahnya dapat dikira-kira sebelumnya maka suatu perusahaan akan memperhitungkan adanya ganti rugi dari asuransi di dalam ia menilai biaya yang harus dikeluarkan oleh perusahaan.

${ }^{10}$ Djoko Prakoso, Op. Cit., hal. 9 
4) Asuransi merupakan dasar pertimbangan dari pemberian suatu kredit. Apabila seseorang meminjam kredit bank, maka ban biasanya meminta kepada debitur untuk menutup asuransi benda jaminn.

5) Asuransi dapat mengurangi timbulnya kerugian-kerugian. Dengan ditutupnya perjanjian asuransi, maka risiko yang mungkin dialami seseorang dapat ditutup oleh perusahaan asuransi.

6) Asuransi merupakan alat untuk membentuk modal pendapatan atau untuk harapan masa depan. Dalam hal ini fungsi menabung dari asuransi terutama dalam asuransi jiwa.

7) Asuransi merupakan alat pembangunan. Dalam hal ini premi yang terkumpul oleh perusahaan asuransi dapat dipakai sebagai dana investasi dalam pembangunan, bantuan kredit jangka pendek, menengah maupun jangka panjang, bagi usaha-usaha pembangunan.

Herman Darmawi, dalam bukunya menyebutkan salah satu manfaat asuransi yaitu asuransi dapat mengurangi kekhawatiran, fungsi primer dari asuransi adalah mengurangi kekhawatiran akibat ketidak pastian. Bila seseorang telah membayar premi asuransi, mereka terbebas dari kekhawatiran kerugian besar dengan memikul suatu kerugian kecil (dalam hal ini berupa premi yang telah di bayar). Kerugian kecil itu sesunggungnya merupakan bagian yang di pikulnya untuk kerugian kelompok itu. Dengan membayar premi, ia memperoleh kepastian biaya kemungkinan kerugian, jika tidak ada asuransi maka mereka yang menghadapi risiko tidak akan dapat meramalkan apakah mereka akan tertimpa kerugian besar, kerugian kecil atau tidak. ${ }^{11}$

\section{JENIS-JENIS ASURANSI}

Kitab Undang-Undang Hukum Dagang di dalam Pasal 247 menyebutkan tentang 5 (lima) macam asuransi, yaitu:

\footnotetext{
${ }^{11}$ Herman Darmawi, Manejemen Asuransi, Bumi Aksara, Jakarta, 2004, hal: 7
}

Volume. 9/No. I/Januari 202I A1-Iqtishod|6I 
Asuransi Dalam pandangan Ekonomi Islam ....

I. Asuransi terhadap kebakaran

2. Asuransi terhadap bahaya hasil pertanian

3. Asuransi terhadap kematian orang (asuransi jiwa)

4. Asuransi terhadap bahaya di laut dan perbudakan

5. Asuransi terhadap bahaya dalam pengangkutan didarat dan di sungaisuangai.

Buku I Kitab Undang-Undang Hukum Dagang mengatur tentang jenis asuransi yang poin I, poin 2 dan poin 3 di atas, sedangkan jenis asuransi yang poin 4 dan 5 diatur di dalam Buku II Kitab Undang-Undang Hukum Dagang. Dari jenis-jenis asuransi yang disebutkan dalam Kitab Undang-Undang Hukum Dagang, dapat dilakukan penggolongan besar sebagai berikut:

I. Asuransi kerugian atau asuransi umum yang terdiri dari asuransi kebakaran dan asuransi pertanian

2. Asuransi jiwa

3. Asuransi pengangkutan laut, darat dan sungai.

Analisis tentang pengaturan asuransi dalam Kitab Undang-Undang Hukum Dagang menunjukkan bahwa lingkup pengaturan Kitab Undang-Undang Hukum Dagang menitik beratkan pada asuransi kebakaran saja sementara telah terdapat berbagai jenis asuransi lainnya yang memerlukan pengaturan. Terlepas dari keterbatasan dalam penggolongan tersebut diatas, Kitab Undang-Undang Hukum Dagang memungkinkan jenis penutupan asuransi secara luas, sesuai dengan ketentuan Pasal 268 Kitab Undang-Undang Hukum Dagang yang berbunyi: “ Suatu pertanggungan dapat mengenai segala kepentingan yang dapat dinilaikan dengan uang, dapat diancam oleh sesuatu bahaya, dan tidak dikecualikan oleh undang-undang."

Namun, definisi tersebut tidak lagi mencukupi karena kepentingan yang diasuransikan tidak lagi terbatas pada kepentingan yang dapat dinilaikan dengan uang sebagaimana halnya dengan jiwa seseorang. Kebutuhan masyarakat telah jauh 
Mochammad Andre Agustianto

melampaui kebutuhan terhadap asuransi kebakaran semata untuk mempertanggungkan kepentingan mereka mengingat risiko-risiko yang timbul kemudian melahirkan kebutuhan terhadap jenis-jenis asuransi baru. Batasan atas objek asuransi dalam Pasal 268 Kitab Undang-Undang Hukum Dagang meliputi objek asuransi atas kepentingan yang dapat dinilaikan dengan uang, dapat diancam oleh suatu bahaya yang tidak dikecualikan oleh undang-undang sudah tidak sesuai praktik industri sudah sejak lama.

Dari ketentuan Pasal 247 dan 268 Kitab Undang-Undang Hukum Dagang dapat diartikan bahwa walaupun terdapat banyak keterbatasan dalam ketentuanketentuan Kitab Undang-Undang Hukum Dagang, ketentuan-ketentuan tersebut tidak menutup munculnya jenis-jenis asuransi yang baru sepanjag ketiga kriteria tersebut di atas dapat dipenuhi semua dalam kesepakatan di antara para pihak yang akan mengikatkan diri.

Bentuk-bentuk asuransi yang dikenal dalam tata hukum Indonesia, yakni sebagaimana tertuang dalam Undang-Undang Nomor 2 Tahun 1992 tentang Usaha Perasuransian dan peraturan pelaksanaannya, dapat dijabarkan sebagai berikut:

I. Asuransi jiwa

Asuransi jiwa dapat didefenisikan dari dua perspektif, yaitu lingkungan masyarakat dan perorangan. Dari sudut pandang lingkungan masyarakat, asuransi jiwa dapat didefenisikan sebagai perangkat sosial pengalihan risiko keuangan perorangan akibat kematian ke kelompok orang, dan melibatkan suatu proses akumulasi dana oleh kelompok untuk memenuhi kerugian keuangan yang tidak pasti akibat kematian.

Dari sudut pandang perorangan, asuransi jiwa dapat didefenisikan sebagai suatu perjanjian (polis asuransi) yang mana satu pihak (pemilik polis) membayar suatu perangsang kepada pihak lain (penanggung) sebagai imbalan persetujuan penanggung untuk membayar jumlah tertentu jika 
Asuransi Dalam pandangan Ekonomi Islam ....

orang yang ditanggung meninggal. Dimana kegunaan asuransi jiwa adalah memberikan perlindungan ekonomis terhadap kerugian yang mungkin terjadi akibat suatu kemungkinan kejadian, seperti kematian, sakit, atau kecelakaan.

2. Asuransi Kerugian

Asuransi kerugian dikelompokkan ke dalam 2 kelompok besar, yakni:

a. Asuransi wajib (compulsory insurance)

Adalah asuransi wajib dilaksanakan oleh setiap orang yang berkepentingan sehubungan dengan adanya undang-undang atau peraturan pemerintah mengenai hal tersebut.

Contoh dari asuransi ini antara lain adalah asuransi dana kecelakaan lalu lintas jalan dan dana kecelakaan penumpang, dikenal dengan asuransi Jasa Raharja, diatur berdasarkan UndangUndang Nomor 33 tahun 1964 dan Undang- Undang Nomor 34 tahun 1964.

b. Asuransi sukarela (voluntary insurance)

Karena sifatnya sukarela maka setiap orang tidak terikat untuk masuk pada jenis asuransi ini, yaitu: Asuransi Jiwa (Life Insurance) dan Asuransi Kerugian (Non Life Insurance) atau General Insurance, seperti: asuransi kebakaran, kecelakaan diri, kendaraan bermotor, dll.

\section{Metode Penelitian}

Untuk mengkaji penelitian ini maka digunakan metode kualitatif dengan melakukan pendekatan metode studil iteratur (library research).Penelitian ini dilakukan dengan membaca serta melakukan berbagai hal terutama mempelajari 
berbagai literature- literatur yang ada, yang didapatmelaluimetode documenter, yang bersumberdaribuku, jurnal, internet, danmakalah. ${ }^{12}$

Setelah semua data terkumpul kemudian data akan dianalisis dengan beberapa cara, diantaranya yaitu: Pertama, Interprestasi, adalah upaya tercapainya pemahaman yang benar terhadap fakta, data dan gejala. Kedua, koheresi intern, yaitu agar pemikiran tokoh dapat dipahami secara tepat, maka seluruh konsep pemikirannya dilihat menurut keselarasannya antara satu dengan yang lain. Ketiga, holistika adalah pandangan menyeluruh atau totalitasi; semua dipandang dalam kesinambungannya dengan satu totalitas. Keempat, heuristika yaitu berdasarkan bahan-bahan baru, metodologi baru, maka peneliti berusaha untuk menemukan pemahaman baru.

Setelah semua data terkumpul dan telah dilakukan analisa, maka dapat dijelaskan secara umum bagaimana hendaknya penelitian ini disusun secara disiplin agar isinya dapat dipahami secara runtut dan analistis.

\section{Hasil dan Pembahasan}

Dikalangan ummat Islam ada anggapan bahwa asuransi itu tidak Islami. Orang yang melakukan asuransi sama halnya dengan orang yang mengingkari rahmat Allah. Allah-lah yang menentukan segala-segalanya dan memberikan rezeki kepada makhlukNya, sebagaimana firman Allah SWT, yang artinya :

Dan tidak ada suatu binatang melata pun dibumi melainkan Allah-lah yang memberi rezekinya." (Q. S. Hud: 6) "Dan siapa (pula) yang memberikan rezeki kepadamu dari langit dan bumi? Apakah di samping Allah ada Tuhan (yang lain)???" (Q. S. AnNaml: 64) "Dan kami telah menjadikan untukmu dibumi keperluan-keprluan hidup, dan (kami menciptakan pula) makhluk-makhluk yang kamu sekali-kali bukan pemberi rezeki kepadanya." (Q. S. Al-Hijr: 20)

Dari ketiga ayat tersebut dapat dipahami bahwa Allah sebenarnya telah menyiapkan segala-galanya untuk keperluan semua makhluk-Nya, termasuk manusia sebagai khalifah di muka bumi. Allah telah menyiapkan bahan mentah, bukan bahan matang. Manusia masih perlu mengolahnya, mencarinya dan mengikhtiarkannya.

${ }^{12}$ Sugiyono, MetodePenelitianBisnis, (Alfabeta: Bandung, 20I4), hal. 399

Volume. 9/No. I/Januari 202I A1-Iqtishod | 65 
Asuransi Dalam pandangan Ekonomi Islam ....

Melibatkan diri ke dalam asuransi ini, adalah merupakan salah satu ikhtiar untuk menghadapi masa depan dan masa tua. Namun karena masalah asuransi ini tidak dijelaskan secara tegas dalam nash, maka masalahnya dipandang sebagai masalah ijtihadi, yaitu masalah yang mungkin masih diperdebatkan dan tentunya perbedaan pendapat sukar dihindari.

Masalah asuransi dalam pandangan ajaran Islam termasuk masalah ijtihadiyah, artinya hukumannya perlu dikaji sedalam mungkin karena tidak dijelaskan oleh AlQuran dan Al-Sunnah secara eksplisit. Para imam mujtahid seperti Abu Hanifah, Imam Malik, Imam Syafi'I, Imam Ahmad bin Hanbal dan para mujtahid yang semasa dengannya tidak memberikan fatwa mengenai asuransi karena pada masanya asuransi belum dikenal. System asuransi baru dikenal di dunia Timur pada abad XIX Masehi. Dunia Barat sudah mengenal system asuransi ini sejak abad XIV Masehi, sedangkan para ulama mujtahid besar hidup pada sekitar abad II s.d. IX Masehi.

Dikalangan ulama atau cendekiawan Muslim terdapat empat pendapat tentang hukum asuransi, yaitu:

I. Mengharamkan asuransi dalam segala macam dan bentuknya seperti sekarang ini, termasuk asuransi jiwa. Kelompok ini antara lain Sayyid Sabiq yang diungkap dalam kitabnya FIqh Al-Sunnah, Abdullah Al-Qalqili, Muhammad Yusuf AlQardhawi, dan Muhammad Bakhit Al-Muth'I, alasannya antara lain:

- Asuransi pada hakikatnya sama dengan judi,

- Mengandung unsure tidak jelas dan tidak pasti,

- Mengandung unsure riba/rente,

- Mengandung unsure eksploitasi karena apabila pemegang polis tidak bias melanjutkan pembayaran preminya, bias hilang atau dikurangi uang premi yang telah dibayarkan,

66| Al-Iqtishod Volume. 9/No. I/Januari 202I 
- Premi-premi yang telah dibayarkan oleh para pemegang polis diputar dalam praktik riba (karena uag tersebut dikreditkan dan dibungakan),

- Asuransi termasuk akad shafi, artinya jual beli atau tukar-menukar mata uang tidak dengan uang tunai,

- Hidup dan matinya manusia dijadikan objek bisnis, yang berarti mendahului takdir Tuhan Yang Maha Esa.

2. Membolehkan semua asuransi dalam praktiknya dewasa ini. Pendapat ini dikemukakan oleh Abdul Wahab Khalaf, Mustafa Ahmad Zarqa, Muhammad Yusuf Musa dan alasan-alasan yang dikemukakannya sebagai berikut:

- Tidak ada nash Alquran maupun nash Al-Hadis yang melarang asuransi,

- Kedua pihat yang berjanji (asurador dan yang mempertanggungkan) dengan penuh kerelaan menerima operasi ini dilakukan dengan memikul tanggungjawab masing-masing,

- Asuransi tidak merugikan salah satu atau kedua belah pihak dan bahkan asuransi menguntungkan kedua belah pihak,

- Asuransi mengandung kepentingan umum, sebab premi-premi yang terkumpul dapat diinvestasikan (disalurkan kembali untuk dijadikan modal) untuk proyek-proyek yang produktif dan untuk pembanguna,

- Asuransitermasuk akad mudharabah, maksudnya asuransi merupakan akad kerja sama bagi hasil antara pemegang polis (pemilik modal) dengan pihak perusahaan asuransi yang mengatur modal atas dasar bagi hasil (profit and loss sharing),

- Asuransi termasuk syirkah ta’awuniyah,

- Dianalogikan atau diqiaskan dengan system pension, seperti taspen,

Volume. 9/No. I/Januari 202I A1-Iqtishod|67 
Asuransi Dalam pandangan Ekonomi Islam ...

- Operasi asuransi dilakukan untuk kemaslahatan umum dan kepentingan bersama,

- Asuransi menjaga banyak manusia dari kecelakaan harta benda, kekayaan, dan kepribadian.

Dengan alasan-alasan yang demikian, asuransi dianggap membawa manfaat bagi pesertanya dan perusahaan asuransi secara bersamaan. Praktik atau tindakan yang dapat mendatang kemaslahatan orang banyk dibenarkan oleh agama.

Lebih jauh Fuad Mohammad Fachruddin menjelaskan bahwa asuransi social, seperti asuransi kesehatan dan asuransi kecelakaan, diakibatkan oleh pekerjaan, Negara melakukannya terhadup setiap orang yang membayar iuran premi yang ditentukan untuk itu, Negara pula yang memenuhi kekuragan yang terdapat dalam perbedaan uang yang telah dipungut dengan uang pembayar kerugian. Maka asuransi ini menuju ke arah kemaslahatan umum yang bersifat social. Oleh karena itu, asuransi ini dibenarkan oleh agama Islam. ${ }^{13}$

Asuransi terhadap kecelakaan, jika asuransinya tergolong kepada asuransi campur (asuransi yang didalamnya termasuk penabungan). Hakikat asuransi campur mencakup dua premi, yaitu untuk menutup bahaya kematian dan untuk menyiapkan uang yang harus dibayar jika dia tidak meninggal dunia dalam jangka waktu yang telah ditentukan, maka hukumnya dibolehkan oleh agama Islam karena asuransi campur didalamnya terdapat dorongan untuk menabung dan penabungan itu untuk kemaslahatan umum. Syaratnya, perusahaan asuransi berjanji kepada para pemegang polis bahwa uang preminya tidak dikerjakan untuk pekerjaan-pekerjaan riba, hal ini sama dengan hokum penabungan pada pos, adapun asuransi biasa menurut Fuad Mohammad Fachruddin tidak dibolehkan, karena asuransi ii tidak meuju kearah kemaslahatan umum dan kepentingan bersama.

${ }^{13}$ Fuad Muhammad Fachruddin, Riba dalam Bank, Koperasi, Perseroan dan Asuransi, Bandung: PT. AlMa'arif, I985, hal: 30

68| A1-Iqtishod Volume. 9/No. I/Januari 202I 
3. Membolehkan asuransi yang bersifat social dan mengharamkan asuransi yang bersifat komersial semata. Pendapat ini dikemukakan oleh Muhammad Abu Zahrah. Alasan yang dapat digunakan untuk membolehka asuransi yang bersifat social sama dengan alasan pendapat kedua, sedangka alasan pengharaman asuransi bersifat komersial semata-mata pada garis besarnya sama dengan alasan pendapat pertama.

4. Menganggap bahwa asuransi bersifat syubhat karena tidak ada dalil-dalil syar'i yang jelas mengharamkan ataupun secara jelas menghalalkannya. Apabila hukum asuransi dikategorikan syubhat, konsekuensinya adalah umat Islam dituntut untuk berhati-hati (al-ihtiyath) dalam menghadapi asuransi. Umat Islam baru dibolehkan menjadi polis atau mendirikan perusahaan asuransi apabila dalam keadaan darurat.

Rancangan asuransi yang dipandang sejalan dengan nilai-nilai Islam diajukan oleh Muhammad Nejatullah Shiddiqi sebagai berikut: ${ }^{14}$

I. Semua asuransi yang menyangkut bahaya pada jiwa manusia, baik mengenai anggota badan maupun kesehatan harus ditangani secara eksklusif dibawah pengawasan Negara. Jika nyawa anggota badan atau kesehatan manusia tertimpa akibat kecelakaan pada industry atau ketika sedang melaksanakan tugas yang diperintahkan oleh majikannya, beban pertolongan dang anti rugi dibebankan pada pemilik pabrik atau majikanya.

2. Prinsip yang sama dapat diterapkan ketika mmemutuskan masalah pengangguran, apakah tindakan yang harus dilakukan oleh majikan atau pemilik pabrik setelah mengakibatkan menganggurnya orang yang bersangkutan. Bersama dengan ini haruslah individu diberi kebebasan mengambi asuransi guna menangguangi kerugian yang terjadi pada kepentingan dirinya dan keluarganya

${ }^{14}$ Muhammad Nejatullah Shiddiq, Asuransi di Dalam Islam, alih bahasa oleh Ta'lim Musafir, Bandung: Pustaka, I985, Hal: 58-60

Volume. 9/No. I/Januari 202I A1-Iqtishod | 69 
Asuransi Dalam pandangan Ekonomi Islam ...

oleh berbagai kecelakaan sehingga ia dapat memelihara produktivitas ekonomi serta kelanjutan bisnisnya.

Asuransi seperti diatas juga harus menjadi kepentingan Negara dengan membawa semua asuransi ke bawah wewenang dilaksanakan oleh Negara. Negara harus mengambil langkah-langkah untuk melindungi kekayaan dan harta milik orang banyak dari kebakaran, banjir, kerusakan gempa bumi, badai, dan pencurian. Kesempatan haruslah diberikan kepada setiap individu untuk mengambil asuransi terhadap kerugian financial yang terjadi. Uang ganti rugi hendaklah ditetapkan dalam setiap kasus menurut persetujuan kontrak sebelumnya yang menjadi dasar pembayaran premi oleh pemilik kekayaan. Dalam hal seseorang jatuh miskin disebabkan oleh suatu musibah, orang tersebut harus ditolong dari kemiskinannya dengan system jaminan social. Jaminan ini mesti dapat diperoleh tanpa pembayaran premi apapun. Akan cocok kiranya jika perusahaan-perusahaan besar seperti industry pesawat terbang wajib untuk diasuransikan, rumah tempat tinggal juga dapat dipertimbangkan menurut jalur-jalur ini, badan swasta yang melakukan usaha asuransi bagi barang-barang kekayaan juga dapat diizinkan.

Hendaklah sebagian besar bentuk asuransi yang berkaitan denganjiwa, perdagangan laut, kebakaran, dan kecelakaan dimasukkan dalam sector Negara. Beberapa di antaranya yang berurusan dengan kecelakaan-kecelakaan tertentu, hak-hak, dan kepentingan-kepentingan serta kontrak-kontrak yang biasa diserahkan kepada sektor swasta.

\section{E. Simpulan}

Dari uraian penjelasan diatas dapat disimpulkan sebagai berikut:

I. Asuransi adalah suatu perjanjian ,dengan mana seorang penanggung mengikatkan diri kepada seorang tertanggung, dengan menerima suatu premi untuk memberikan 
penggantian kepadanya karena suatu kerugian, kerusakan atau kehilangan keuntungan yang di harapkan, yang mungkin akan dideritanya karena suatu peristiwa yang tidak tentu.

2. Tujuan asuransiitu mempunyai tujuan untuk mengalihkan suatu resiko yang mengancam harta kekayaan atau jiwa seorang penanggung dan mengganti kerugian pada tertanggung sesuai dengan perjanjian diantara kedua belah pihak yaitu tertanggung dan penanggung sejak diawal perjanjian.

3. Manfaat asuransiyaitu:
a) Memberikan rasa terjamin atau rasa aman dalam menjalankan usaha
b) Dapat menaikkan efisiensi dan kegiatan perusahaan
c) Merupakan dasar pertimbangan dari pemberian suatu kredit
d) Dapat mengurangi timbulnya kerugian-kerugian
e) Merupakan alat untuk membentuk modal pendapatan atau untuk harapan masa depan

4. Hukum asuransi dalam islam digolongkan menjadi 4 berdasarkan pendapat para ulama cendekiawan islam yaitu:

a) Haram, karena didalamnya mengandung unsur ketidakjelasan dan termasuk judi (Sayyid Sabiq yang diungkap dalam kitabnya FIqh Al-Sunnah)

b) Mubah, karena tidak ada dalil nash Al-Quran maupun Hadist yang melarangnya (Abdul Wahab Khalaf, Mustafa Ahmad Zarqa, Muhammad Yusuf Musa)

c) Membolehkan asuransi social dan mengharamkan asuransi komersial (Muhammad Abu Zahrah)

d) Syubhat, karena tidak ada dalil syar'i yang mengharamkannya

\section{F. Daftar Pustaka}

Kambali, Muhammad. "MEKANISME PENGELOLAAN DANA TABARRU' ASURANSI SYARIAH PRUDENTIAL LIFE ASSURANCE.” JES (Jurnal Ekonomi Syariah), 20I7. https://doi.org/I0.30736/jes.v2iI.30.

Volume. 9/No. I/Januari 202I A1-Iqtishod|7I 
Asuransi Dalam pandangan Ekonomi Islam ....

Subekti. 200I. Pokok-Pokok Hukum Perdata. PT. Intermasa: Jakarta

Alim, Abbas. 2003.Asuransi dan Manejemen Resiko. PT.Raja Grafindo Persada: Jakarta

Darmawi, Hermani. 2004.Manejemen Asuransi. Bumi Aksara: Jakarta

Muhammad, Abdulkadi. I993. Hukum perdata Indonesia. Citra Aditya Bakti: Bandung

Shiddiqi, Muhammad Nejatullah. 1985. Asuransi di Dalam Islam. alih bahasa oleh Ta'lim Musafir. Pustaka: Bandung

Fachruddin, Fuad Muhammad. I985 Riba dalam Bank, Koperasi, Perseroan dan Asuransi. PT. Al-Ma’arif: Bandung

Prakoso, Djoko, I. Ketut Murtika. I989. Hukum Asuransi di Indonesia.Rineka Cipta: Jakarta

Kitab Undang-Undang Hukum Dagang

Sugiyono, MetodePenelitianBisnis, (Alfabeta: Bandung, 2014), hal. 399

72| A1-Iqtishod Volume. 9/No. I/Januari 202I 